\title{
High-Frequency Carrier-Type Magnetic Field Sensor with a Sub-pT Resolution Using a Magnetic Film and a Transmission Line
}

\author{
Y. Murayama, T. Ozawa ${ }^{* 1}$, S. Yabukami*2, K. Ishiyama, and K.I. Arai ${ }^{* * * 3, * * * * 4}$ \\ Research Institute of Electrical Communication, Tohoku Univ., Katahira 2-1-1, Aoba-ku, Sendai 980-8577, Japan
}

\begin{abstract}
We developed a very sensitive high-frequency carrier-type magnetic field sensor with a sub-pT resolution using a resonating transmission line. Meander-type sensor elements using amorphous CoNbZr films were fabricated. We obtained a magnetic field resolution of $7.4 \times 10^{-13} \mathrm{~T} / \mathrm{Hz}^{1 / 2}$ at $501 \mathrm{kHz}$. The detectable magnetic field was limited by the noise caused by nonlinear magnetic excitation. We analyzed the quality factor of the resonance for enhancement of the signal-to-noise ratio.
\end{abstract}

Key words: sub pT resolution, resonating transmission line, thin-film sensor, quality factor

\section{$10^{-13} \mathrm{~T}$ 台の磁界検出分解能を有する高周波伝送線路型薄膜磁界センサ}

\author{
村山芳隆・小澤哲也 ${ }^{* 1} \cdot$ 薮上信*2 $・$ 石山和志・荒井賢一**3, ****4
}

東北大学電気通信研究所，仙台市青葉区片平 2-1-1（９９80-8577）

\section{1. はじめに}

高透磁率磁性体へ高周波電流やパルス波を通電し，外部 磁界を印加することで，その透磁率変化を介し，表皮効果 及び自然共鳴によりインピーダンスが大きく変化すること を利用した磁界センサは，GMI センサあるいは高周波キャ リア型磁界センサと呼ばれ、高感度化の研究及び産業応用 が議論されている ${ }^{1)-5)}$.この磁界センサの検出感度の限界は 磁化の熱ゆらぎで決定されると考えられ，その值は室温で $10^{-13} \mathrm{~T}\left(7.95 \times 10^{-8} \mathrm{~A} / \mathrm{m}\right)$ 台に達するとの報告がある ${ }^{6)}$ 。この 磁界センサを高感度化するにはセンサ素子自体の感度を高 めるとともに，信号検出時のノイズの抑制が重要である.

筆者らは, これまで磁性膜に直接高周波電流を通電させ たタイプのセンサを開発してきた。磁性膜に直接通電する タイプの高周波キャリア型薄膜磁界センサではノイズレ ベルは主として位相雑音と熱雑音で決まることが報告さ れている ${ }^{5)}$. またセンサへの投入パワーを増加させること による SN 比の悪化およびノイズレベルの上昇についての 実験結果を報告した ${ }^{7}$.

本稿ではキャリア電流を大きくした場合のノイズレベル の上昇を緩和することを意図し，磁性薄膜への直接通電を 避ける構造のセンサ素子を検討した。センサ素子はキャリ ア電流を通電させる伝送線路と，近接配置した磁性薄膜か ら構成した。.また共振を利用することでインピーダンス変 化率を増大し，信号強度増大を図った。試作したセンサを 用いて $501 \mathrm{kHz}$ の交流磁界において $10^{-13} \mathrm{~T}\left(7.95 \times 10^{-8} \mathrm{~A} / \mathrm{m}\right)$ 台の磁界検出分解能を得た.

\section{2. 伝送線路型薄膜磁界センサ}

Fig. 1 は本論文で検討する磁界センサを模式的に示し たものである。センサ素子はマイクロストリップ線路等 の伝送線路の上部あるいは上下に磁性薄膜を近接配置 した構造となっている．伝送線路と磁性薄膜の間はレジ ストで絶縁される．磁性薄膜の磁化容易軸は熱処理によ

*1 宮城高等工業専門学校

${ }^{*} * 2$ 東北学院大学工学部

***3 電気磁気材料研究所

****4 情報通信研究機構
って伝送線路の幅方向に付与する。バイアス磁界および交 流磁界（測定磁界）は伝送線路の長手方向へ印加する。 キ ヤリア電流は伝送線路へ通電される. 外部からの印加磁界 によって磁性薄膜の磁化が回転し, 透磁率が変化する。こ れにより伝送線路のインピーダンスが変化し，これを利用 して交流磁界を検出する. 以下本稿ではこの構造の磁界セ ンサを伝送線路型センサと呼ぶ.

Fig. 2 は微小交流磁界の計測方法を概念的に示したもの である.キャリア電流はシグナルジェネレータによりセン サ素子へ加えられ, 出力信号はスペクトラムアナライザ等 の $50 \Omega$ 系の測定装置で計測される. センサ素子には, バイ アス磁界をインピーダンス変化率が最大となるように印 加している. スペクトラムアナライザで計測されるキャリ ア電流は交流磁界により振幅変調され，その側波帯は交流 磁界の磁界強度に比例する. 信号強度は線形領域での励振であ れば，振幅変調波の側波帯 ${ }^{8)}$ として(1)式で近似できる.

$$
\left|v_{o}\left(\omega_{c} \pm \omega_{s}\right)\right|=\frac{J S\left(Z_{b}+50\right) R_{o} h_{a c}}{2\left\{Z_{b}+R_{o}+R_{i}\right\}^{2}}\left(\frac{d Z}{d h}\right)
$$

ただし $v_{o}$ は側波帯レベル， $\omega_{c}$ はキャリアの角周波数， $\omega_{s}$

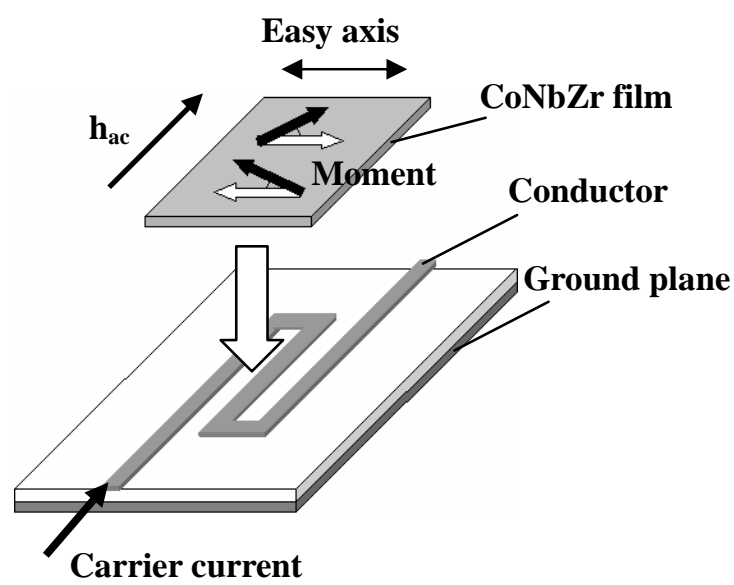

Fig. 1 Schematic view of the sensor element. Journal of the Magnetics Society of Japan Vol. 31, No. 1, 2007 


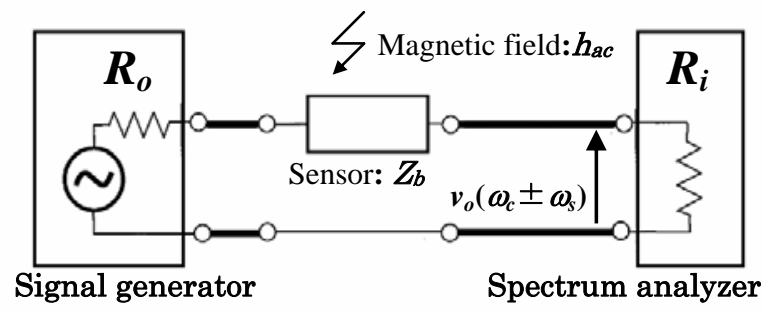

Fig. 2 Equivalent circuit.

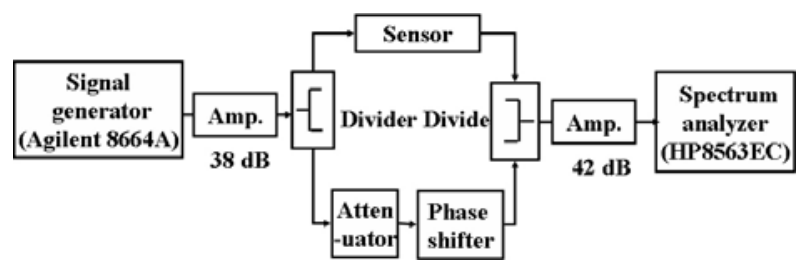

Fig. 3 Carrier-suppressing circuit.

は微小交流磁界の角周波数， $J$ はセンサ素子に通電する キャリアの電流密度, $\mathrm{S}$ はセンサ素子の断面積, $h_{a c}$ は測 定される交流磁界強度， $R_{o}$ はシグナルジェネレータの出 力抵抗, $R_{i}$ はスペクトラムアナライザの入力抵抗であり, $Z_{b}$ は素子の動作点におけるインピーダンス, $\mathrm{dZ} / \mathrm{d} h$ は印 加磁界に対するインピーダンス変化率である.

\section{3. 実験方法}

\section{1 センサ素子の作製}

センサ素子はマイクロストリップ線路上にアモルファス $\mathrm{Co}_{55} \mathrm{Nb}_{12} \mathrm{Zr}_{3}$ 薄膜を近接配置した構造となっている. マイク ロストリップ線路は, 厚さ $0.5 \mathrm{~mm}$ のテフロン基板 (CHUCOH 製 CGK-500)，あるいは厚さ $25 \mu \mathrm{m}$ のポリイ ミド基板（SHIN-ETSU 製 RBF-1）をウェットエッチング によって作製した． $\mathrm{Co}_{85} \mathrm{Nb}_{12} \mathrm{Zr}_{3}$ 薄膜は RF スパッタ法により 投入電力は $200 \mathrm{~W}, \mathrm{Ar}$ ガス圧は 20 mTorr の条件でガラス基板 (MATSUNAMI製 S-1111) に約 $4 \mu \mathrm{m}$ 成膜した。 その後熱処 理は回転磁界中熱処理 (2 時間, $3 \mathrm{kOe}(238.5 \mathrm{kA} / \mathrm{m})$, $\left.400^{\circ} \mathrm{C}\right)$ の後, 静磁界中熱処理 (1 時間, $3 \mathrm{kOe}(238.5 \mathrm{kA} / \mathrm{m})$, $150^{\circ} \mathrm{C} ）$ を施した。 ${ }_{0}{ }_{5} \mathrm{Nb}_{12} \mathrm{Zr}_{3}$ 薄膜の異方性磁界強度は 19.9 $\mathrm{A} / \mathrm{m}(0.25 \mathrm{Oe})$ となった。 熱処理後, 磁性薄膜表面に絶縁層 としてレジスト（ZEON 製 ZPN-1150）を約 $5 \mu \mathrm{m}$ 塗布し た。作製したマイクロストリップ線路と磁性薄膜を重ね合 わせて伝送線路型センサとした。磁性膜厚（約 $4 \mu \mathrm{m} ）$ およ び絶縁膜厚（約 $5 \mu \mathrm{m} ）$ は本論文の中で試作したセンサにお いては最も SN 比が高くなることから実験的に求めた。作 製したセンサ素子のインピーダンスは，伝送線路長手方向に 直流磁界をへルムホルツコイルで印加しながら, ネットワ ークアナライザ（HP 8752A）を用いて透過法により測定し た.

\section{2 微小磁界計測}

微小磁界計測には Fig. 3 に示寸搬送波抑制回路（キャリ アサプレス回路） ${ }^{5}$ を用いた。シグナルジェネレータ

(Agilent 8664A) から出力されるキャリアは，低雑音増幅 器（NOGAWA NHP-2046）により増幅され，センサ側およ
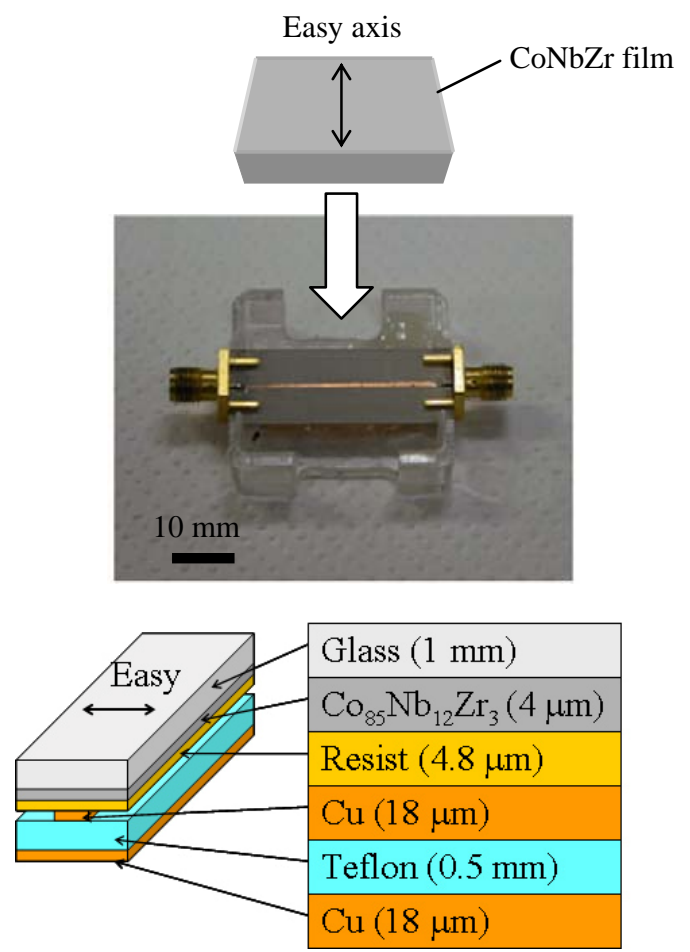

Fig. 4 Sensor element.

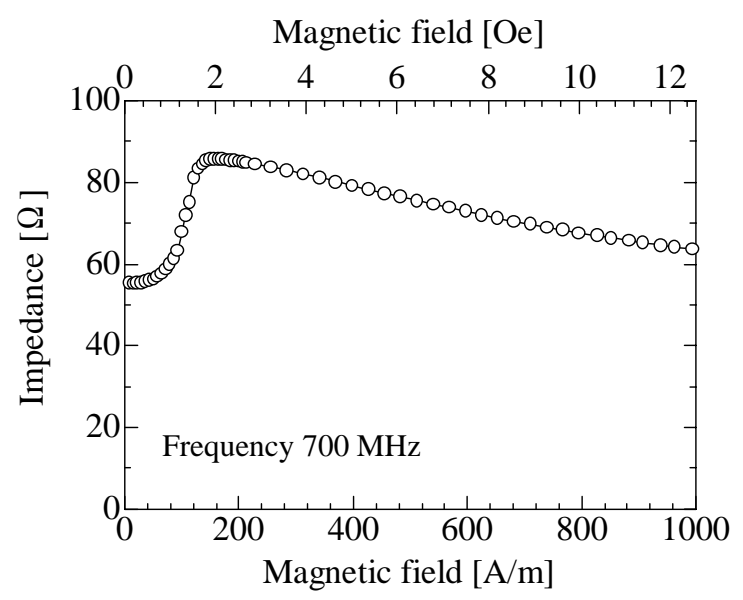

Fig. 5 Impedance of the sensor element.

び減衰器側に分けられる。 センサに印加される交流磁界は センサ素子に通電されるキャリアにより振幅変調される. 分岐されたもう一方ではキャリアを上段と振幅が等しく位 相が $180^{\circ}$ 異なるように，移相器（ARRA 2448A）および 減衰器（Agilent 8494B，KEYCOM KAT-001010-M）によ り調整した。これらの信号を合成することでキャリア成分を $60 \mathrm{~dB}$ 以上抑制し，オフセット周波数 $501 \mathrm{kHz}$ における位相雑音 を熱雑音以下に低減した. 側波帯強度およびノイズレベルの測定は スペクトラムアナライザ（HP8563EC）を用いた。実験は全て， 磁気シールドルーム (遮蔽率は $1 \mathrm{~Hz}$ で約 $35 \mathrm{~dB}, 500 \mathrm{kHz}$ で約 60 dB) で行った.

\section{4. 実験結果}

\section{1 直線状センサ素子}

Fig. 4 に作製したセンサ素子の外観写真および断面の模 式図を示す．伝送線路部分は厚さ $0.5 \mathrm{~mm}$ のテフロン基板 


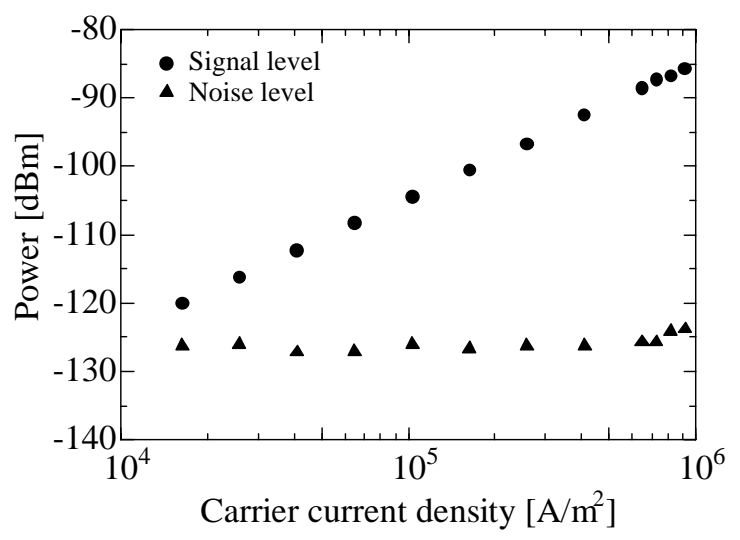

Fig. 6 Signal level and noise level as functions of the carrier current density.

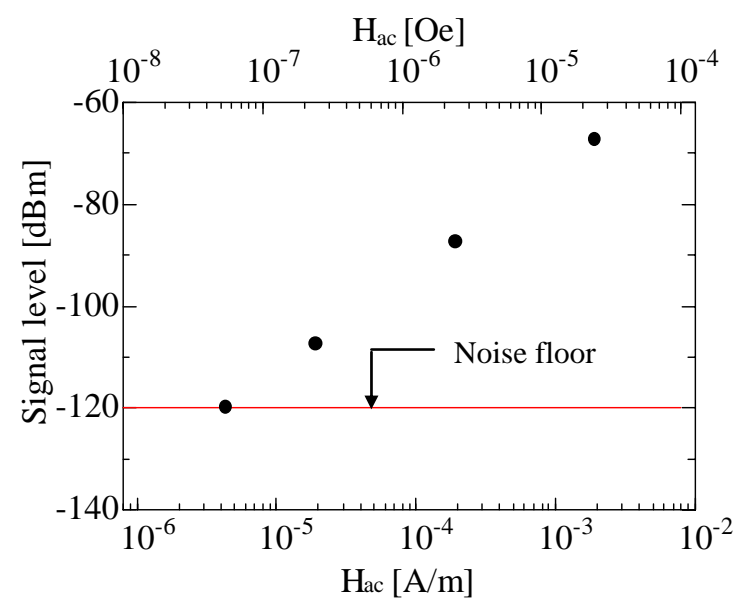

Fig. 7 Signal level as a function of the ac magnetic field.

を使用し, 幅 $0.8 \mathrm{~mm}$, 長さ $30 \mathrm{~mm}$, 厚さ $18 \mu \mathrm{m}$ の直線形 状とした。磁性膜を設置しない状態では特性インピーダン

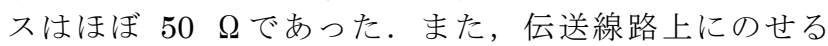
$\mathrm{Co}_{85} \mathrm{Nb}_{12} \mathrm{Zr}_{3}$ 薄膜は一辺 $25 \mathrm{~mm}$ の正方形, 厚さ $4 \mu \mathrm{m}$ とし た. 磁性膜上に塗布したレジスト厚さは約 $5 \mu \mathrm{m}$ とした.

Fig. 5 に Fig. 4 のセンサのインピーダンスと印加磁界の グラフを示す. キャリア周波数が $700 \mathrm{MHz}$ においてインピ ーダンス変化率の最大值は $47.8 \Omega / \mathrm{Oe}(0.601 \Omega /(\mathrm{A} / \mathrm{m}))$ であった。

Fig. 6 に Fig. 4 のセンサの信号強度及びノイズレベルの 通電電流密度依存性のグラフを示す.キャリア周波数は 700 $\mathrm{MHz}$ とした. 測定交流磁界は周波数 $501 \mathrm{kHz}$ ，振幅は $2.4 \mathrm{x}$ $10^{-6} \mathrm{Oe}\left(1.9 \times 10^{-4}(\mathrm{~A} / \mathrm{m})\right)$ とした. Fig. 6 より伝送線路型セン サによる磁界検出が可能であることが示された．センサの 通電電流密度を上げた場合，ノイズレベルの上昇は磁性体 に直接通電する場合と比較して小さかった。 これは磁性体 への直接の通電を避けることで，キャリア電流による大振 幅励磁が起きにくくなるためと考えられる.

Fig. 7 は Fig. 4 のセンサの SN 比が最大となる条件にお ける測定交流磁界強度と信号強度のグラフである。交流磁 界強度と信号強度は比例関係にあり，信号強度がノイズフ ロアと同じレベルとなるときの交流磁界強度がこのセンサ の磁界検出分解能となる。 この実験では, 交流磁界周波数 $501 \mathrm{kHz}$ において磁界検出分解能 $5.4 \times 10^{-8} \mathrm{Oe} / \mathrm{Hz}^{1 / 2}(5.4 \mathrm{x}$ $\left.10^{-12} \mathrm{~T} / \mathrm{Hz}^{1 / 2}\right)\left(4.3 \times 10^{-6}(\mathrm{~A} / \mathrm{m}) / \mathrm{Hz}^{1 / 2}\right)$ を得た。

\section{2 共振を利用したセンサ素子}

伝送線路型センサを共振状態で動作させることで，セン サ素子のインピーダンス変化率を大きくし, 信号強度の増 大を意図したセンサ素子を試作した。

Fig. 8 に共振を利用したセンサ素子の外観写真および断 面の模式図を示す．伝送線路部分は厚さ $0.5 \mathrm{~mm}$ のテフロ ン基板を使用し, 幅 $0.8 \mathrm{~mm}$, 長さ $10 \mathrm{~mm}$, 厚さ $18 \mu \mathrm{m}, 3$ ターンのミアンダ形状とした。 また，伝送線路上にのせる $\mathrm{Co}_{85} \mathrm{Nb}_{12} \mathrm{Zr}_{3}$ 薄膜は一辺 $25 \mathrm{~mm}$ の正方形, 厚さ $4 \mu \mathrm{m}$ とし た. 磁性膜上に塗布したレジスト厚さは約 $5 \mu \mathrm{m}$ とした.

Fig. 9 に Fig. 8 のセンサのインピーダンスと印加磁界の グラフを示す. 周波数 $600 \mathrm{MHz}$, 印加磁界 $68 \mathrm{~A} / \mathrm{m}(0.86 \mathrm{Oe})$ のとき，共振によってセンサ素子のインピーダンスが大き く変化した。 このときインピーダンス変化率の最大值は約 $41000 \Omega / \mathrm{Oe}(515.3 \Omega /(\mathrm{A} / \mathrm{m}))$ を得た。磁性膜の共鳴周波 数付近に共振周波数を設計することにより，所望の寸法条 件で共振が発生するセンサ素子の作製が可能と考えられ る.

Fig. 10 に Fig. 8 のセンサの信号強度およびノイズレベル の素子通電電流密度依存性のグラフを示す. キャリア周波 数は $600 \mathrm{MHz}$ とした。測定交流磁界は周波数 $501 \mathrm{kHz}$ ，振 幅は $2.4 \times 10^{-6} \mathrm{Oe}\left(1.9 \times 10^{-4}(\mathrm{~A} / \mathrm{m})\right)$ とした。バイアス磁界は センサ素子で SN 比が極大となるように設定した。

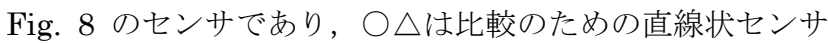

（Fig. 4）である. 共振を利用した Fig. 8 のセンサの信号強 度は直線状センサに比較して約 $30 \mathrm{~dB}$ 大きかった。これは 共振状態におけるインピーダンスの大きくなった効果とマ イクロストリップ線路の長さがより長いためである.

一方，ノイズレベルの上昇は共振を利用した Fig. 8 のセ ンサの方が顕著であった. $\mathrm{SN}$ 比の最大值を比較すると, 共 振を利用した Fig. 8 のセンサのほうが約 $18 \mathrm{~dB}$ 大きくなっ た。

Fig. 11 は Fig. 8 のセンサの SN 比が最大となる条件にお ける測定交流磁界強度と信号強度のグラフである。交流磁 界強度と信号強度は比例関係にあり，信号強度がノイズレ ベルと同じレベルとなるときの交流磁界強度がこのセンサ の磁界検出分解能となる. この実験では, 交流磁界周波数 $501 \mathrm{kHz}$ において磁界検出分解能 7.6 x 10 $0^{-9} \mathrm{Oe} / \mathrm{Hz}^{1 / 2}(7.6 \mathrm{x}$ $\left.10^{-13} \mathrm{~T} / \mathrm{Hz}^{1 / 2}\right)\left(6.1 \times 10^{-7}(\mathrm{~A} / \mathrm{m}) / \mathrm{Hz}^{1 / 2}\right)$ を得た。

\section{3 マイクロストリップ導体の上下層に磁性膜を配置したセン サ素子}

伝送線路の上下に磁性膜を配置することでより効果的に インピーダンス変化を得ることが可能と考えられる。そこ で，伝送線路の両面に磁性膜を配置したセンサ素子を作製 した. Fig. 12 に作製したセンサ素子の外観写真および断面 の模式図を示す．伝送線路部分は厚さ $25 \mu \mathrm{m}$ のポリイミド 基板を使用し, 幅 $0.6 \mathrm{~mm}$, 長さ $20 \mathrm{~mm}$, 厚さ $18 \mu \mathrm{m}, 4$ ターンのミアンダ形状とした。 また，伝送線路を挟む 2 枚 の $\mathrm{Co}_{85} \mathrm{Nb}_{12} \mathrm{Zr}_{3}$ 薄膜は一辺 $25 \mathrm{~mm}$ の正方形, 厚さ $4 \mu \mathrm{m}$ と した。磁性膜上に塗布したレジスト厚さは約 $5 \mu \mathrm{m}$ とした。

Fig. 13 に Fig. 12 のセンサのインピーダンスと印加磁界 のグラフを示寸. 周波数 $570 \mathrm{MHz}$, 印加磁界 $238 \mathrm{~A} / \mathrm{m}$ のと き，共振によってセンサ素子のインピーダンスが大きく変 化した。このときインピーダンス変化率の最大值は約 $11000 \Omega / \mathrm{Oe}(138.4 \Omega /(\mathrm{A} / \mathrm{m}))$ を得た. Fig. 12 のセンサ 


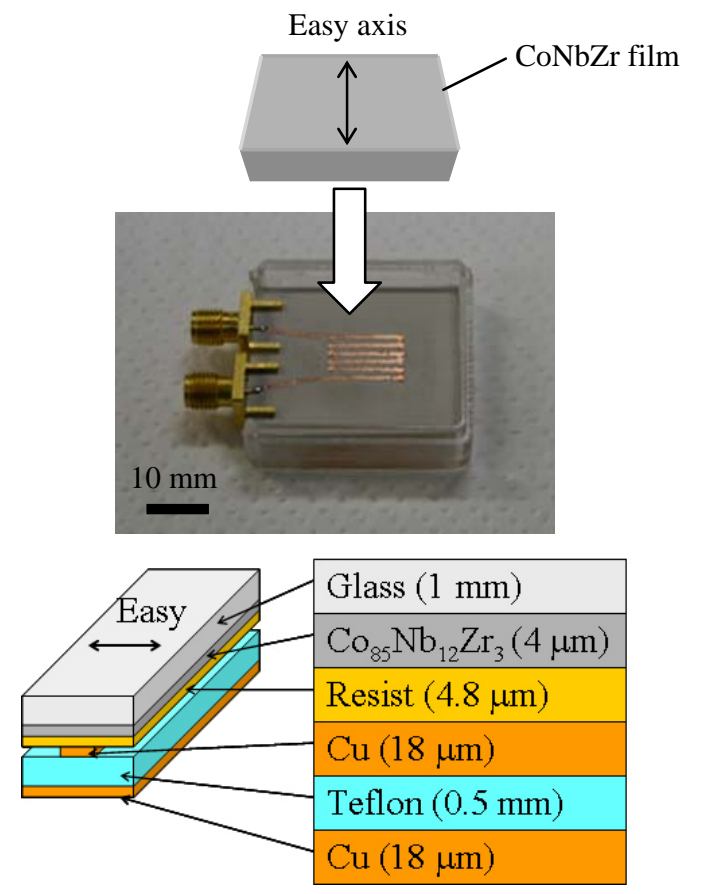

Fig. 8 Sensor element.

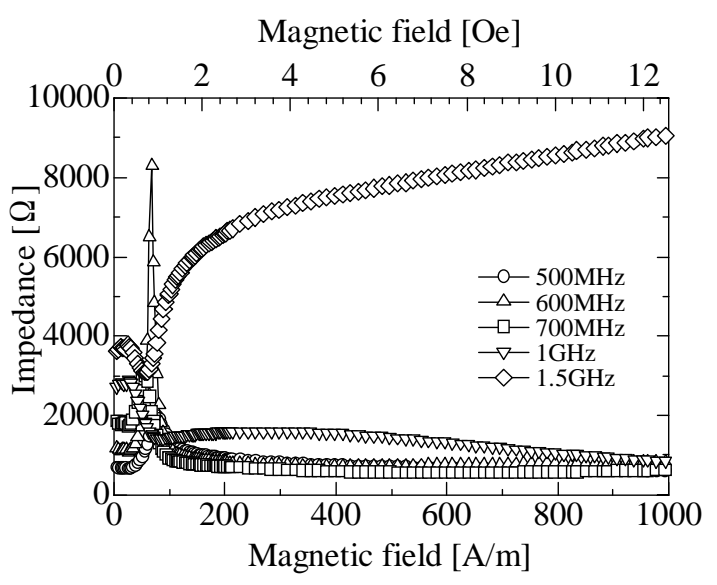

Fig. 9 Impedance of the sensor element.

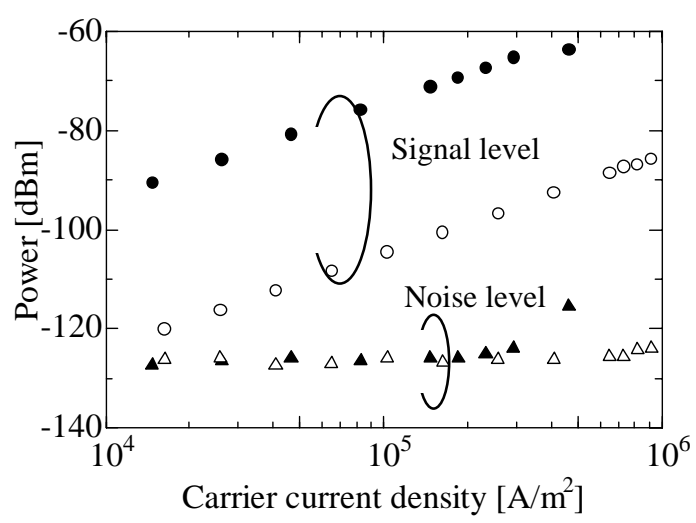

- $\Delta$ Using LC resonance $\circ \Delta$ Without LC resonance

Fig. 10 Signal level and noise level as functions of the current density.

において磁界検出分解能は, 交流磁界周波数 $501 \mathrm{kHz}$ にお いて磁界検出分解能 7.4 x $10^{-9} \mathrm{Oe} / \mathrm{Hz}^{1 / 2}\left(7.4 \times 10^{-13}\right.$

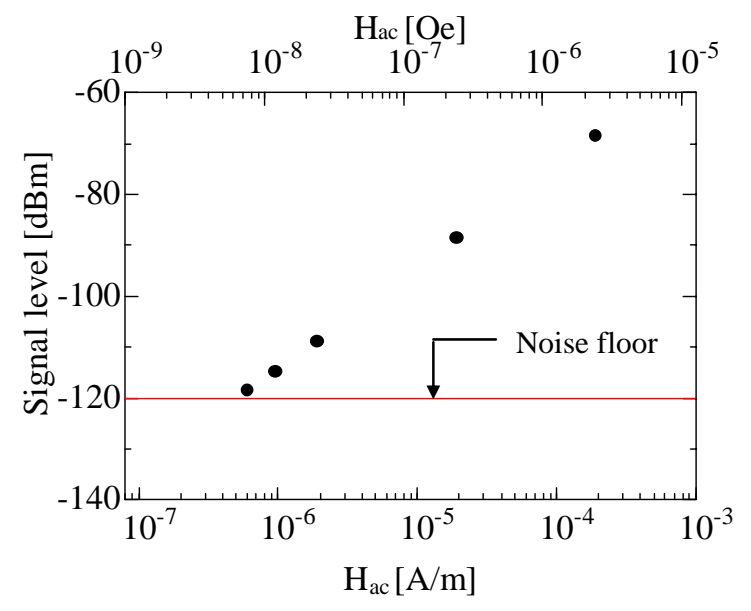

Fig. 11 Signal level as a function of the ac magnetic field.
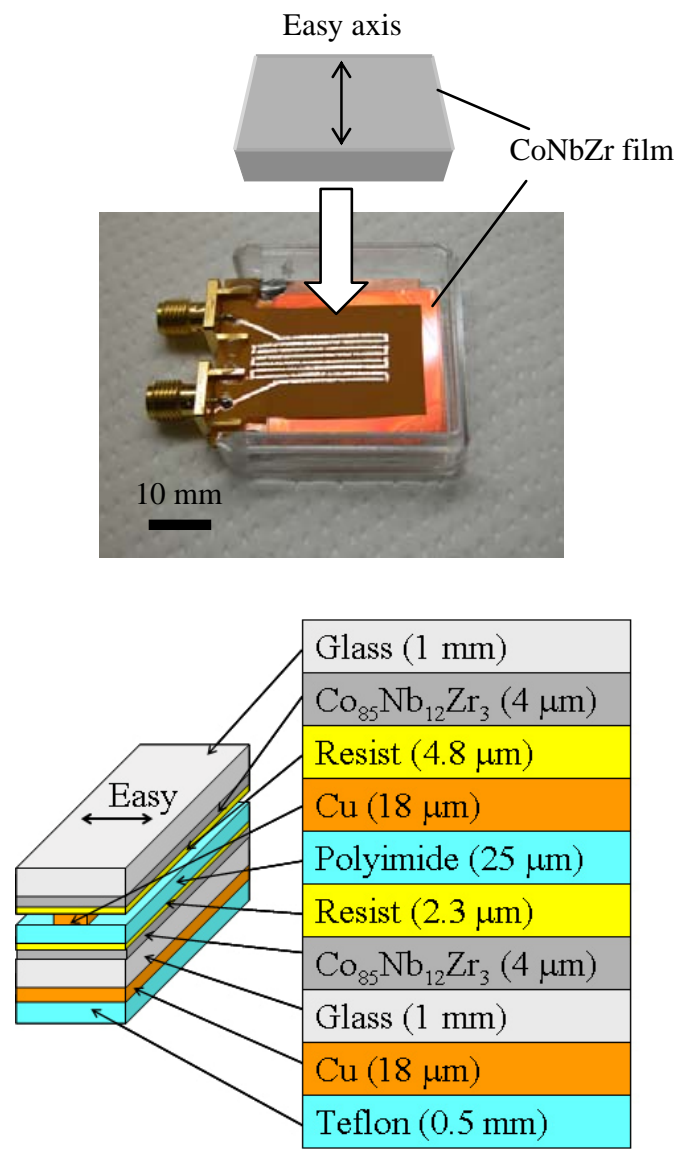

Fig. 12 Sensor element.

$\left.\mathrm{T} / \mathrm{Hz}^{1 / 2}\right)\left(5.9 \times 10^{-7}(\mathrm{~A} / \mathrm{m}) / \mathrm{Hz}^{1 / 2}\right)$ を得た。

\section{3 センサの SN 比に関する考察}

以上の実験結果を踏まえて, 共振を用いた本論文のセン サの SN 比の向上の要因について考察する. 本論文で試作 したセンサ素子は共振時におけるインピーダンスの変化を 検出しているため, インピーダンス変化率の最大值は共振 の性能指数（共振の鋭さ）にほぼ比例すると考えられる. Fig. 14 はセンサの信号強度およびノイズレベルのキャリア 電流密度に対するグラフを示した. Table1には上記の 3 種 類のセンサについて共振子としての性能指数 $(\mathrm{Q})$, インピ 


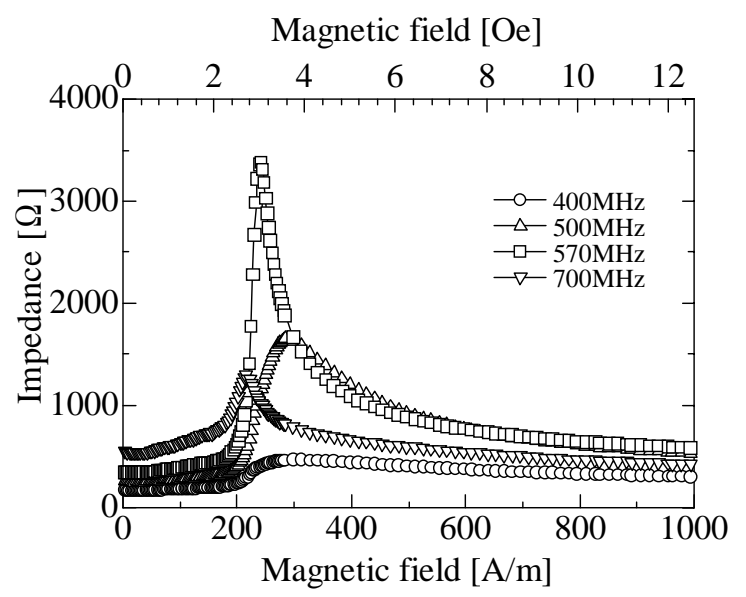

Fig. 13 Impedance of the sensor element.

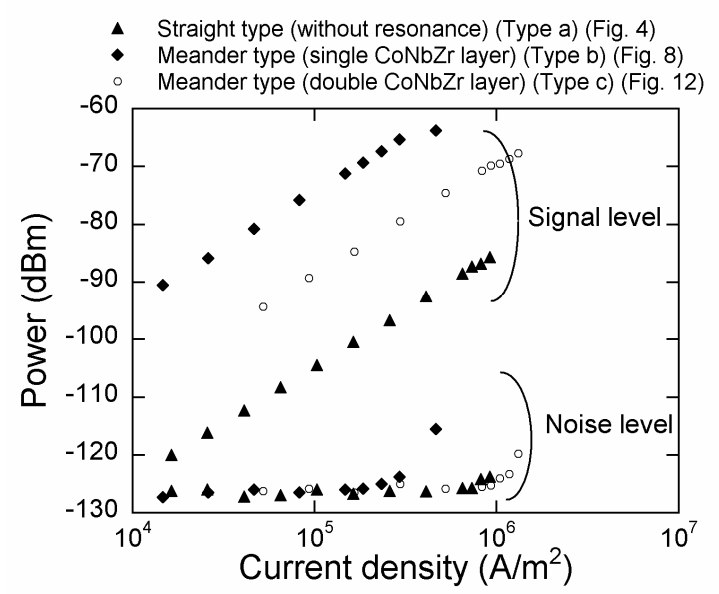

Fig. 14 Signal level and noise level as functions of the current density.

Table 1 Relationship between $\mathrm{Q}, \mathrm{dZ} / \mathrm{dH}$ and current density when noise increased.

\begin{tabular}{|c|c|c|c|}
\hline Sensor & $\begin{array}{l}\text { Quality } \\
\text { factor }\end{array}$ & $\begin{array}{l}\text { Impedance } \\
\text { change } \\
(\Omega /(\mathrm{A} / \mathrm{m}))\end{array}$ & $\begin{array}{l}\text { Current density when } \\
\text { noise increased }\left(\mathrm{A} / \mathrm{m}^{2}\right)\end{array}$ \\
\hline $\begin{array}{l}\text { Straight type } \\
\text { (Type a) (Fig. 4) }\end{array}$ & - & 0.6 & $9.0 \times 10^{5}$ \\
\hline $\begin{array}{l}\text { With a single } \\
\text { CoNbzr layer } \\
\text { (Type b) (Fig. 8) }\end{array}$ & 32.7 & 515.3 & $3.0 \times 10^{5}$ \\
\hline $\begin{array}{l}\text { With double } \\
\text { CoNbZr layers } \\
\text { (Type c)(Fig. 12) }\end{array}$ & 9.2 & 138.4 & $1.0 \times 10^{6}$ \\
\hline
\end{tabular}

ーダンス変化率 $(\mathrm{dZ} / \mathrm{dh})$ の最大值, ノイズレベルが熱雑音レ ベルから $3 \mathrm{~dB}$ 以上上昇しはじめる電流密度を示す。センサ は直線状センサ（センサ a）（Fig. 4)，ミアンダ型導体の上 部に単層の CoNbZr 薄膜を配置したセンサ(センサ b )(Fig. 8 ), ミアンダ型導体の両面に CoNbZr 薄膜を配置したセン サ（センサ c ）（Fig. 12）について示した。測定交流磁界は周 波数 $501 \mathrm{kHz}$, 振幅は $2.4 \times 10^{-6} \mathrm{Oe}\left(1.9 \times 10^{-4}(\mathrm{~A} / \mathrm{m})\right)$ とした. バイアス磁界は $\mathrm{SN}$ 比が極大となるように設定した。

Table1 において性能指数は周波数に対するインピーダン スの極大值付近における半值幅から求めた. センサ b (Fig. 8)はセンサc（Fig. 12）と比較して性能指数は約 3.6 倍,

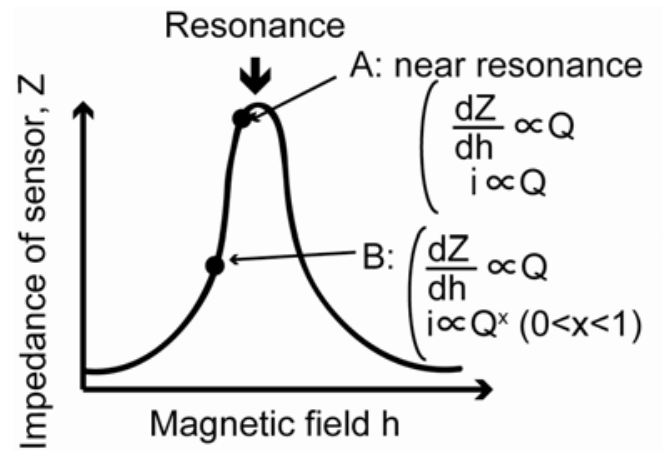

Fig. 15 Impedance of the sensor element.

インピーダンス変化率は約 3.7 倍となり, インピーダンス変 化率は性能指数にほぼ比例した。

一方ノイズレベルの上昇は, 性能指数が大きいほど顕在化 すると考えられる.本センサで扱うノイズはキャリア電流の 増大により, 磁性膜表面において磁界強度が増大し, 磁化の 非線形応答に起因するものと考えられる.すでに通電するキ ヤリア電流の増大に依存して,ノイズが増大寸る実験結果が 得られている ${ }^{9)}$. 並列共振時にセンサ内部では, キャリア電 流が大きくなるため，ノイズレベルが上昇したと考えられ る。一般に知られているように, 並列共振回路中のインダク タンス素子内部を流れる電流 $i$ は(2)式のように性能指数に 比例して与えられる.

$$
i=-j Q I=-j(L / C)^{1 / 2} I / R
$$

ただし， $L ， R$ および $C$ はそれぞれ並列共振回路の抵抗， インダクタンス, キャパシタンスを表す.Iは共振回路の外 から与えた等価電流源（定数）である。(2)式より，共振回 路の性能指数が大きいほど共振回路内部の電流が大きくな り, 磁性膜の非線形駆動に起因したノイズレベルが上昇する と考えられる.なおこのノイズレベルの上昇のメカニズムに ついては稿を改めて詳細に報告する.

Table 1 においてノイズの上昇する電流密度は Fig. 14 に おいてノイズレベルが熱雑音のレベルから $3 \mathrm{~dB}$ 以上上昇す る時のキャリア電流密度とした. なおこの電流密度は伝送線 路の断面に均一に電流が流れていることを仮定して求めた ものであり，実際には表皮効果が顕在化することから，素子 表面では Table 1 の電流密度よりも大きな電流密度になっ ていると考えられる. Table 1 によれば，ノイズが上昇する 時の電流密度は単層磁性膜を用いたセンサb (Fig. 8)におい て, 両面に磁性膜を用いたセンサ c (Fig. 12)に比較して, 約 3.3 倍であり, 共振時の性能指数の比率 (3.6) よりも若干小 さかった.これは実際のバイアス点が共振点よりも低いイン ピーダンスにおいて動作しているため,ノイズの上昇が性能 指数に比例する傾向よりも緩和されたためと考えられる.

Fig. 15 には共振を用いることでセンサの SN 比が向上す る理由を模式的に示した. 動作点を並列共振点にほぼ一致さ せると (A 点), センサの信号強度は性能指数にほぼ比例し, さらにノイズレベルを決める共振回路の内部電流は性能指 数に比例するため, SN 比は向上しないと考えられる.

一方実際のセンサ素子の動作点はバイアス磁界を調整し て, 共振点よりも低バイアス側に設定されている (B 点). これによりインピーダンスの変化率はほぼ性能指数に比例 し, かつ共振回路の内部の電流は共振点の電流よりも小さく 
設定できるため，センサの SN 比は向上したものと考えら れる. 本センサの SN 比を向上させる基本的設計指針とし ては性能指数を可能な限り大きくしつつ, 共振回路内部の 電流を低減させることが必要であると考えられる。本セン サは更なる高感度化に向けて, 最適導体寸法の検討, 伝送 線路の選定，内部導体パターンの選択，素子全体の薄膜デ バイス化，サイズと磁界検出分解能の関係についての検討 が必要である.

\section{5. まとめ}

1. $\mathrm{Co}_{85} \mathrm{Nb}_{12} \mathrm{Zr}_{3}$ 薄膜を用いた高周波キャリア型薄膜磁界 センサにおいて磁性体への直接の通電を避ける構造の 伝送線路型センサを作製した。

2. 伝送線路型センサを用いることで，センサへの投入パ ワー増大に伴うノイズレベルの上昇を緩和した。

3. 磁性膜を導体パターンの上下層に使用した伝送線路型 センサにおいて共振を利用して $11000 \Omega / O e （ 138.4$ $\Omega /(\mathrm{A} / \mathrm{m}))$ のインピーダンス変化率を得た。試作した センサで $501 \mathrm{kHz}$ の交流磁界を 7.4 x $10^{-9}$ $\mathrm{Oe} / \mathrm{Hz}^{1 / 2}\left(7.4 \times 10^{-13} \mathrm{~T} / \mathrm{Hz}^{1 / 2}\right)\left(5.9 \times 10^{-7}(\mathrm{~A} / \mathrm{m}) / \mathrm{Hz}^{1 / 2}\right)$ の 磁界検出分解能で測定した.

4. 本センサは正確に共振点で動作させれば，センサの信 号強度およびはほぼ性能指数に比例し, SN 比は向上 しないと考えられる. 本センサは共振点よりも低バイ アス側で動作させるため，信号強度はほぼ性能指数に 比例し，ノイズレベルの増大が抑制されたため SN 比 が向上したと考えられる。
謝辞 本研究の一部は経済産業省地域新生コンソーシア 厶（16G2012）及び文部科学省の科学研究費補助金 基盤 A(16206041)による研究成果である.

\section{References}

1) H. Yamadera, Y. Nishibe, T. Morikawa and Y Nonomura, T.IEE Japan, vol. 118-A, pp. 689-694, Oct. 1998.

2) D. Atkinson and P.T. Squire, IEEE Trans. Magn., vol. 33, pp.3364-3366, 1997.

3) A. Takayama, T. Uehara, A. Yuguchi, H. Kato, K. Mohri and T. Uchiyama, , IEEE Trans. Magn., vol. 35, pp. 3643-3645, 1999.

4) D. Robbes, C. Dolabdjian, Y. Monfort, and P. Ciureanu, Physica C, vol. 372-376, pp. 249-253, 2002.

5) S. Yabukami, T. Suzuki, N. Ajiro, H. Kikuchi, M. Yamaguchi, and K. I. Arai, IEEE Trans. Magn, 37, 2019 (2001).

6) M. Takezawa : Doctoral dissertation of Tohoku University, p. 216 (1999)

7) Y. Murayama, T. Ozawa, S. Yabukami, K. Ishiyama, and K.I. Arai:, J. Magn. Soc. Jpn, 30, 237 (2006).

8) H. Kikuchi : Doctoral thesis of Tohoku university. (2002)

9) S. Yabukami, Y. Murayama; K. Ishiyama; K.I. Arai, H. Okuno, The Intermag2005 Conference, FV-09 (2006).

2006 年 8 月 8 日受理, 2006 年 11 月 13 日採録 